\title{
Interreligious University Theologies, Christian/Islamic
}

Oddbjørn Leirvik

Faculty of Theology, University of Oslo, Oslo, Norway

\section{ABSTRACT}

With reference to the establishment of new chairs and centres for Islamic theology at Northern European universities, this article discusses how Christian and Islamic university theology may develop into a multi- or interreligious way of doing theology. Will these initiatives change the ways in which theology is done in academia, through institutionalized cooperation between theologians from different traditions? Having introduced the academic field of 'interreligious studies" the author further defines the term 'interreligious theology' in relation to confessional theology and comparative theology and argues that interreligious ways of doing theology are characterized by their relational and interactive approach, with a strong emphasis on agency. The article further explores the institutionalized aspect of interreligious theology - citing the classical example of Muslims and Christians reflecting together in medieval Baghdad, the late modern practice of 'scriptural reasoning', and the pluralization of theology in contemporary academia. Having noted the tension between inter- and trans-religious ways of doing theology, the article critically explores the metaphors of 'third space', 'spaces in between', and 'home'.

\section{Keywords:}

Interreligious studies; university theology; comparative theology; doing theology

In the European context, the term 'university theology' has been used to refer to theology being done in the context of secular universities (typically, in separate faculties of theology) and in critical dialogue not only with the churches but also with the academy and with the wider society. In this article, I shall expand the term to include modes of doing theology across religious traditions, in a common institutional framework (i.e., the academy).

The context of my reflections is the introduction of Islamic theology in the form of new chairs, study programmes and research initiatives in Northern European universities. The largest initiatives are found in the new German centres for Islamic studies/Islamic theology, which were established on the initiative of the German research council (Wissenschaftsrat) at five universities from 2011 onwards. ${ }^{1}$ My own Faculty of Theology at the University of Oslo

\footnotetext{
${ }^{1}$ Their English designations are: Institute for Islamic Theology (Osnabrück), Centre for Islamic Theology (Münster and Tübingen), Department for Islamic-Religious Studies (Erlangen-Nürnberg) and Institute for the Study of Islamic Culture and Religion (Frankfurt). The centre in Frankfurt does, however, include theology in the
} 
has offered courses in Islamic theology, philosophy and ethics since 2011 and established a permanent position in 'theological studies in Islam' in 2016. Similar developments are seen in other theological faculties/departments in Northern Europe, which now include Islamic theology and, in some cases, other theological traditions. ${ }^{2}$

The new initiatives aimed at institutionalizing what I shall call 'Islamic university theology' reflect, of course, the growing presence of Muslims in Europe. To be relevant, university theology must relate critically and constructively to the lived diversity of beliefs and practices among European Muslims, and their multifaith surroundings. At first glance, the cues of 'university theology' and 'lived religion' might seem to point in different directions academic and theoretical versus popular and practical. But just as academic theology may relate dynamically to lived religion, lived religion may have theological implications and even ambitions to influence the way in which theology is done in the academy.

This interactive understanding of theology also applies to interreligious ways of doing theology (as explored in the present article), which carry the common features of 'contextual theology' across religious differences, critically conscious of the cultural, social and political frameworks of doing theology (Pears 2010).

The emergence of contextually oriented, Islamic university theologies deserves separate investigation. Do nascent forms of Islamic university theology relate constructively to Europe's religious diversity? How is Islamic theology formatted in a secular university context? And how will Islamic university theology in Europe balance tradition-oriented studies reflecting the specific taxonomy and terminology of the classical Islamic sciences with a theological discourse about religion, ethics and hermeneutics that also communicates with the academic community and with wider society? For example, in 2015 Mouhanad Khorchide - the director of the Centre for Islamic Theology in Münster, Germany - dedicated a book to the issue of Islam and humanism, in dialogue with the European humanistic tradition (Khorchide 2015). The book may be indicative of how Islamic university theology directs its attention to general issues in the wider society (such as humanism), transcending religion-specific and traditionoriented discourses (see Leirvik 2016b).

The aim of this explorative article is to investigate the relational aspect of doing theology in a university context, seeing the university as a potential meeting place for different

title of its journal, which has been published since 2014: Frankfurter Zeitschrift für Islamisch-Theologische Studien.

${ }^{2}$ For instance, the Academy of World Religions at the University of Hamburg accommodates a broader array of theological traditions such as Christian, Islamic, Alevite, Jewish, Buddhist and Hindu. 
theologies and a shared site for doing theology across religious traditions. My main focus will be Christian and Islamic theologies and their potential academic interaction, although I shall also discuss the concept of interreligious theology in a more general sense.

As I have argued elsewhere (Leirvik 2014), the relational approach to religion and theology can be seen as a defining feature of 'interreligious studies' as an academic field. Relationality may mean many things, including the relation between lived religion and academic theology. What I shall discuss in the following, is whether 'university theology' can be seen as a dialogical practice field in its own right - where theology is done in conversation between religious practitioners and scholars from different religious traditions. It is this interactive way of doing theology across religious traditions, in a shared institutional context, that I have characterized as 'interreligious university theologies' (Leirvik 2016a). It should be emphasized from the outset that I see interreligious theology as but one aspect of interreligious studies. Interreligious studies may just as well be done from a social science perspective, as from a theological one.

\section{Interreligious studies}

Historically, the relation between theology and religious studies is conflictual. In the present context, however, both scholarly traditions are being challenged by more relationally oriented paradigms. In tune with my own emphasis on the relational approach, Paul Hedges $(2013,1077)$ sees interreligious studies (in comparison with theology and religious studies) as 'more expressly focused on the dynamic encounter and engagement between religious traditions and persons'.

Ideally, interreligious studies should be done in an interdisciplinary way, drawing upon the broad array of disciplines that make up a modern university. Interreligious studies (as I define it) is also characterized by an interactive way of studying religion and doing theology in a multireligious setting. It thus requires a critical consciousness of being a contextually situated agent - be it of conservation or change.

The agency aspect of doing academic work on religion has traditionally been more accentuated by theology than by religious studies. With regard to the widely felt tension between theology and religious studies in modern universities, Gavin Flood (himself a religious studies scholar) takes a conciliatory approach. In a chapter on 'Dialogue and the Situated Observer' in his book Beyond Phenomenology (1999), Flood criticizes the idea of 'the detached, epistemic subject penetrating the alien world of the other through the phenomenological process'. Instead, he says, 'the subject must be defined in relation to other subjects' (143). Thus 
- as theologians as well as religious studies scholars - we have 'a situation in which research is imaged as 'conversation', or more accurately 'critical conversation', in which the interactive nature of research is recognized'.

Religious studies thus become 'a dialogical enterprise in which the inquirer is situated within a particular context or narrative tradition ...' (143). Seeing the researcher as thrown into a dialogical relationship with people or texts of the object tradition, Flood offers valuable insights for the interaction between the academic study of religion and lived religion, and provides an interesting framework for thinking about university theology as a potential setting for doing contextual theology - in a critical conversation between scholars of different religious traditions.

\section{Theology: confessional, comparative, interreligious}

Returning to the notion of interreligious studies, Hedges $(2013,1077)$ locates it at the 'interface between a more traditionally secular religious studies perspective, and a more traditionally confessional theological discipline'. But theology itself may done in many different way, of which confessional theology is but one.

\section{Confessional theology}

In the Northern European as well as the Northern American context, confessional theology has not been confined to church-related seminaries but has been taught and done as such in a secular university setting (in Protestant and Catholic faculties or divinity schools). Whatever the institutional framework, confessional Christian theology investigates the historical legacy and the contemporary relevance of a particular religious tradition, by means of classical disciplines such as biblical studies, church history, systematic theology and practical theology. Islamic theology too (as it has been done in traditional institutions of learning) has its classical disciplines such as qur'anic interpretation, Hadith studies, jurisprudence, dogmatic theology and philosophy. Confessional Christian as well as Islamic theology also includes practical theology, with the aim of training competent clergy in practical skills such as recitation/liturgical skills, homiletics and (increasingly) counselling.

It should be emphasized that confessional theology is not only done with a view to the needs of the corresponding faith community and its practitioners. In Christian university theology there is a long tradition of doing 'public theology' in increasingly secular societies. According to the Catholic theologian David Tracy (1991, 3, 5), Christian theology has three 'publics': the wider society, the academy and the church. Corresponding visions for public 
theology can be seen in the above-mentioned initiatives to establish chairs and centres for Islamic theology in Western universities. For instance, in the first issue of Frankfurter Zeitschrift für Islamisch-Theologische Studien (published by the Institute for the Study of Islamic Culture and Religion at Goethe University) the authors explicitly link the establishment of Islamic theological studies to the discussion about 'die Existenzberechtigung von Universitätstheologie im Allgemeinen' (see Agai 2014).

Both the academy and society at large include other religions than one's own. Thus, in a modern, multireligious context, theologians will often see it as an integral part of their academic task to prepare students and future clergy for an informed dialogue with other religions. In Scott Daniel Dunbar's $(1998,462)$ view, the descriptive study of religion in academia should be supplemented with a prescriptive study of interreligious relations (trying to find out how dialogue can 'play a role in resolving religious conflicts and healing past injustices'), and also with 'an experiential study which helps students study to understand the dynamics of interreligious dialogue in a more existential way that has practical implications for their own lives'.

In a critical comment on models of interfaith education that might seem to be too much dominated by the insider perspective, David Cheetham argues that interfaith education needs the outsider perspective of religious studies in order not to be controlled by dialogue activists who are well aware of their role as agents but perhaps not always able to see themselves from a critical distance. Cheetham agrees with Dunbar that the study of interreligious dialogue has its legitimate place as a university study, but is critical of Dunbar's emphasis on prescriptive study: 'it is difficult to see how the study of inter-religious relations could be prescribed in such a way that the typical outcomes are "respect", "tolerance" or "a culture of peace and dialogue", (Cheetham 2005, 30).

\section{Comparative theology}

Thus, theology - when engaging in interfaith education - must include a critical perspective on dialogical agency. In a constructive mode, confessional theologies that are open to learning from other traditions are often referred to as comparative theology. ${ }^{3}$ As early as 1987, Tracy $(1987,454)$ suggested that 'any theology in any tradition that takes religious pluralism seriously must eventually become comparative theology'.

\footnotetext{
${ }^{3}$ See the thematic issue of Studies in Interreligious Dialogue 2014 (1), 'Is Comparative Theology Catholic?'
} 
The term 'comparative theology' is related to the term 'comparative religion', which is normally associated with a religious studies perspective on studying religion. Comparative theology, however, distinguishes itself by a more existential and self-implicating approach to the religious traditions. In the understanding of the Catholic theologian Francis Clooney (2010, 10), comparative theology is 'faith seeking understanding' across religious barriers, in theological efforts based in a particular faith tradition but venturing into 'learning from one or more other faith traditions'. In comparison with dialogical or interreligious theology, he sees comparative theology as '... primarily and usually a form of reading', whereas inter-religious dialogue (in his understanding) is 'usually a form of conversation' (Clooney 2013, 54). He notes that comparative theology is interreligious 'in its appropriation of one's own and another tradition in its relation to one another' (Clooney 2010, 11). But, according to Clooney, 'it remains an intellectual and most often academic practice even if, like other forms of theology, it can occur in popular forms as well' (11).

In Clooney's understanding, however, comparative theology is normally not done in conversation with lived religion, but rather in a solitary reading practice focused on texts. Criticizing Clooney's perception, Jeannine Hill Fletcher $(2014,17)$ suggests that the site for comparative Catholic theology should rather be 'embodied practice'. Abstracted thought-forms, she argues, "produce concrete practices that are at odds with the "Catholic" traditions of sacramentality and social justice'. With reference to a case study of the Maryknoll Sisters in China, she argues that the sisters' faith-based engagement with 'the messy embodiment of the everyday practices of women's lives', may actually be seen as a popular way of doing comparative theology (80). In conjunction with Fletcher's reasoning, it should be emphasized that bodily experience, for instance through ritual participation, is just as relevant as a point of reference for theological reflection as literary expressions of the intellectual traditions in question. This means that the phenomenon of 'interrituality' (Moyaert and Geldhof 2015), where people from different faith traditions take part in each other's rituals, should also be part of the picture when discussing comparative and interreligious theology.

\section{Interreligious theology}

What would be the difference between comparative and interreligious theology, then? For Clooney $(2010,10)$, interfaith dialogue (and, probably, ritual participation) functions merely as raw material for theological reflection: 'Dialogical or interreligious theology grows out of interreligious dialogue, as reflection aimed at clarifying dialogue's presuppositions, learning from its actual practice, and communicating what is learned in dialogue for a wider audience.' 
In my understanding, which differs from that of Clooney, the defining features of interreligious (or dialogical) theology are the relational and cooperative aspects of doing theology. Theology done in this way may spring from and relate to ritual participation and interfaith dialogue, but is also dialogical in and of itself.

Another central feature of interreligious theology (and interreligious studies in general) would be that (for example) Christianity and Islam are oriented towards a common third (see Homi Bhabha's employment of the term 'third space', referred to below). When for instance my own Faculty of Theology has developed courses such as 'Biblical and Qur'anic Hermeneutics', 'Jesus, Muhammad and Modern Identities' and 'Islam, Christianity and the West', it is hermeneutics, modern identity discourses and the religions' encounter with the West that constitute the third element. Admittedly, comparative religion - and indeed comparative theology - may also have common thematic orientations in their comparison of elements from different religious traditions. However, in my understanding, interreligious theology distinguishes itself from abstract comparison by inviting researchers, teachers and students from different religious backgrounds to take part in a critical and constructive interpretive work. Thus in their reflections on interreligious theology, Linda Hogan and John d'Arcy May (whose contextual references are Buddhist-Christian and Christian-Hindu dialogue) note that

(t)here is already much activity in the field that has come to be called 'comparative theology', though what we envisage is something more like a 'collaborative theology' which would not stop short at identifying ways of tackling similar or perhaps identical problems but would actually set about doing so. Representatives of different faiths would thus deploy their inherited resources together, working out the methodology for doing so as they went.' (Hogan and May 2011, 76)

\section{Interreligious theology - institutionalized?}

In my perception, interreligious theology also has a most important institutional aspect to it. During the last decade, several Northern European universities have opened up to Islamic theology as a university discipline on a par with Christian theology. This has happened either in the form of separate centres for Islamic theology (as in several German universities), or (as in the Netherlands and in Scandinavia) by establishing new chairs for Islamic theology in traditionally Christian faculties of theology. Similar developments have long ago taken place in theological seminaries and divinity schools in the Anglo-American world. For faculties of theology and theological seminaries, this means that erstwhile Christian institutions of learning and training are slowly becoming multireligious faculties of theology - as 'houses with many 
mansions' (Vroom 2008). Will they also become interreligious faculties and seminaries where theology is done in dialogue between Christian and Islamic traditions, as an interreligious form of public theology?

In the history of Christian-Muslim relations, there are not many examples of doing theology together in a common institutional framework, and in a shared ethical-philosophical horizon. A rare example can be found in the intensive cooperation between Muslims and Christians in Baghdad and surrounding regions in the ninth and tenth centuries, when Muslims and Christians - in a joint intellectual effort sponsored by the caliph - translated a vast part of the Greek philosophical heritage, including works of Plato and Aristotle, into Arabic. In this way, they articulated not just one but two common languages: a Greek language of mind and the written language of Arabic, demonstrating thus the ability to converse meaningfully across their different religious languages. Their historic effort was sponsored by caliphs and emirs and the best-known institutionalization of the project is known as the 'House of Wisdom' (possibly initiated by Caliph Harun al-Rashid and culminating under Caliph al-Ma'mun, who reigned from 813 to 833$)$.

Why did Muslim and Christian intellectuals make this common effort? In tune with the universalistic legacy of Greek philosophy, one of their aims was to write works about virtue ethics in a philosophical language that transcended the boundaries of faith and articulated a common humanity. For instance, the main works of the Muslim philosopher Miskawayh (d. 1030) and his Christian mentor Yahya ibn 'Adi (d. 974) carry the same Greek-inspired title: 'Refinement of the human character'. Earlier in the tenth century, al-Farabi wrote a work entitled 'The virtuous city', which on Platonic and Aristotelian models articulated a common political ethics. Linguistically, it is in this era that Arabic coins a separate word for 'humanity': insāniyya. Humanity was the common horizon of these philosophers, not Muslim or Christian group interest (Kraemer 1986; Leirvik 2002, 122-142). In the words of Miskawayh (1968, 14): 'To this end people must love one another, for each one finds his own perfection in someone else, and the happiness of the latter is incomplete without the former.'

Historically, it was not humanistic philosophy that became the dominant line of thought within classical Islam. But the legacy has proved to be strong enough to serve as an inspiration for dialogue-minded Muslim and Christian philosophers and theologians today. To me, this historical example may serve as an inspiration for interreligious theology in at least three ways: (1) In its interactive nature, (2) in its search for a faith-transcending language, oriented towards our common humanity, and (3) in its shared (although short-lived) institutionalization. 
What examples can be found today of Christians and Muslims doing theology together, in a common institutional framework and with a shared commitment to humanitarian concerns and pressing challenges in today's world? One interesting example is the well-established practice of studying sacred texts between Jews, Christians and Muslims known as 'Scriptural Reasoning' (Ford and Pecknold 2006; Adams 2011). Scriptural Reasoning resembles comparative theology in that it privileges understanding above agreement, but transcends it by joint study and by relating scriptural traditions to specific needs related to pain and suffering in our shared world (Adams 2011, 71).

As for the institutional framework of Scriptural Reasoning, David Ford (2006, 7-13.) has distinguished between conversations in houses, tents and campuses respectively. In addition to the different religions' 'houses' of interpretation, 'tents' may occasionally be pitched to accommodate interreligious dialogues about sacred texts and common socio-political challenges. ${ }^{4}$ Many such projects would have strong personal links with academic institutions. But it is also clear, Ford notes, that 'campuses' may offer a more durable and solid structure for interfaith dialogue - if the academy opens up to such activities. ${ }^{5}$

As I see it, a pressing challenge for interreligious theology is to move forwards from short-lived and 'tent-based' projects towards more solid, 'campus-based' attempts at doing theology together (for instance between Jews, Christians and Muslims). In Europe, it is particularly interesting to see how the new German centres for Islamic theology will develop in this respect, with a view to cooperation between the new Islamic centres and the Catholic and Protestant faculties of theology. To what extent will the Islamic centres and the Christian faculties be doing theology together in an interactive manner, faced with common societal challenges and drawing upon strongly related intellectual traditions?

An interesting model of doing theology interreligiously is the Academy of World Religions at the University of Hamburg, where theologians from Christian, Islamic (Shi'ite), Alevi, Jewish, Buddhist and Hindu traditions work side-by-side in joint theological efforts related to shared societal challenges. In tune with my emphasis on the relational and interactive nature of interreligious (or dialogical) theology, the Academy of World Religions presents itself as 'the institutional home for research, teaching and contributions to society in the area of interreligious dialogue. It embraces a dialogical approach that concerns itself not only with

${ }^{4}$ A German example is the Stuttgart-based Theologisches Forum Christentum-Islam, which has been working since 2005 .

${ }^{5}$ In the case of Scriptural Reasoning, the main academic bases have been Cambridge University, the University of Virginia and Princeton University (Adams 2011, 51). 
religions coexisting but also with their interacting. ${ }^{6}$ In such frameworks, new theological ground may be broken, as people from different religious traditions engage each other in long term dialogue.

\section{Inter or trans?}

Close theological cooperation may also challenge established (and often simplified) notions of difference, which often overemphasize religious difference so that other important variations (such as gender and class) are overshadowed. Another question is how to conceptualize hybrid identities that do not coincide with institutionalized religious differences. In his Interreligious Theology, one of the Academy of World Religions' guest professors, the Jewish scholar Ephraim Meir (2015, 8), introduces the term 'trans-difference', which refers to 'a multireligious identity in which one feels inspired by more than one religious tradition and in which there may even be a double belonging'.

Similarly, the Norwegian theologian Anne Hege Grung has challenged the very notion of 'interreligious' and suggests that 'transreligious' may be a more apt term for capturing the dynamic encounter between lay people and scholars who engage each other in serious explorations beyond the frameworks of more representative forms of dialogue. According to Grung $(2011,31)$, the term transreligious reflects the recognition that boundaries between religions are not stable: 'The focus is more on the individual than on the collective representation in the dialogue, and there is a view that religion has to be interpreted and reinterpreted by its followers.'

An important reference for Grung's suggestion is a project that was carried out at the nexus between lived religion and university theology. In her study Gender Justice in MuslimChristian Readings (2015), Grung analyses how Christian and Muslim women in Norway make meaning of texts from their canonical scriptures that are felt to be problematic from the perspective of the situation of women. What happens when they read these texts (e.g. Q 4.34 and 1 Timothy 2.8-15) together?

The interpretative situation staged and analysed by Grung covered both the encounter between readers and texts, and the encounter between readers. In this case, the participants were brought together in the context of a research project and the relatively neutral arena of the campus may have made it easier to address critical questions to problematic texts in the sacred traditions.

${ }^{6}$ https://www.awr.uni-hamburg.de/website-content/pdfs-flyer/redi-flyer-englisch.pdf. Accessed 30 August 2018. 
Grung's project engaged lay people in a joint interpretative effort across religious boundaries, using a transreligious (i.e., not representative) approach, and with the shared focus of gender (in)justice. On the interreligious scene of today, numerous efforts are being made to bring together lay people and theologians from different religious traditions in critical and constructive conversation on common ethical and theological themes. The question is whether these theological efforts adopt an 'interreligious' method, or rather engage in a 'transreligious' exploration. I would suggest that both approaches to doing theology are necessary, as theology should have a triple reference: to the faith communities and their established traditions (interreligious), to the less formalized expressions of lived religion (transreligious), and to culturalized forms of religion in the wider society (inter- and transreligious).

\section{'These in-between spaces'}

Trying to further conceptualize the nature of interreligious theology, I shall borrow Martin Buber's metaphor of 'the realm of between'. Can we say that that interreligious theology is a form of reasoning that takes place in the spaces between different religious traditions? Admittedly, the notion of a realm of between might seem to have more affinity with the term interreligious (evoking images of stable entities and spaces between them) than with the term transreligious (transcending notions of neat and stable differences). The reason why I still prefer the notion of interreligious is that it better captures the relational aspect of cross-religious encounters and theologies.

Martin Buber's meditations on the realm of between are philosophical and spiritual, and rooted in his perception of the dynamic encounter between I and Thou:

Spirit is not in the I, but between I and Thou. It is not like the blood that circulates in you, but like the air in which you breathe. Man lives in the spirit, if he is able to respond to his Thou. He is able to, if he enters into relation with his whole being.

(Buber 1987, 54)

In a later essay on dialogue, he writes: 'On the far side of the subjective, on this side of the objective, on the narrow ridge, where I and Thou meet, there is the realm of "between"' (Buber 2002, 142).

Maybe Buber's reflections on the realm of between are too idealistic. Emmanuel Levinas criticized Buber for not sufficiently taking account of the asymmetrical nature of human relationships. Suggesting that Buber understands the I-Thou relationship as 'a 
harmonious co-presence, as an eye to eye', Levinas $(1998,150)$ states: 'There would be an inequality, a dissymmetry, in the Relation, contrary to the 'reciprocity' upon which Buber insists, no doubt in error.'

Considering the asymmetry of all human relations, one has to realize that there is no realm without power inequalities. A realm of between may idealistically be defined as a space not owned by one party, much like Jürgen Habermas's notion of the public space as a place for dominion-free conversation. But in real life, all spaces in between are contested.

The contested nature of any space between is also emphasized by Homi Bhabha in his reasoning about the related notion of 'third space'. Bhabha's perspective is that of the production of cultural meaning, but it may also be applied to the act of doing interreligious theology as well. In The Location of Culture, he focuses on 'those moments or processes that are produced in the articulation of cultural difference' (Bhahba 1994, 2). These differences are not static but are played out and transformed in multiple spaces in between. He writes: 'These "in-between" spaces provide the terrain for elaborating strategies of selfhood, singular and communal, that initiate new signs of identity, and innovative sites of collaboration, and contestation, in the act of defining the idea of society itself' (2) And he goes on to suggest that '[i]t is the 'inter' - the cutting edge of translation and negotiation, the in-between space - that carries the burden of the meaning of culture ... by exploring this Third Space, we may elude the politics of polarity and emerge as the others of ourselves' (56)

Emerging as 'the others of our selves' (cf. Ricoeur's [1995] notion of 'oneself as another') may also be a suggestive aim of interreligious theology. The Shi'ite scholar and interfaith activist Hasan Askari (d. 2008) presents a similar type of reasoning about self and other in a 1972 article titled 'The Dialogical Relationship between Christianity and Islam'. Here, Askari went as far as to suggest that the two religions, by their rival understandings of the Word of God, 'constitute one complex of faith', one starting with the Person and the other with Scripture. According to Askari (1972, 485): 'Their separateness does not denote two areas of conflicting truths, but a dialogical necessity.' Seeing Christianity and Islam as 'a dialogical whole', Askari envisages Christians and Muslims trying to interpret the signs of God together, not with the ambition of reaching harmony but rather in an attempt to come to terms with irreducible differences: 'A common religious sign must be differently apprehended. It is the very ambiguity, richness, of the religious sign that gives rise to different and even opposed interpretations and understandings' [in this case, of the Word of God] (485). Sensitive to the pain of difference, he adds: 'To drop monologue is to immediately discover the other ... the 
discovery of the other, of our own being, is both soothing and painful, more the latter .... It is right in the middle of this pain and anxiety that a Divine Sign is known' (485).

'The discovery of the other, of our own being ...' - Aksari's reasoning is evocative, but can it be cited as an instance of interreligious theology? To put it differently: are we just evoking metaphors here, or do we refer to real places where theology is actually done across lived experiences and religious traditions? In a chapter in The New Comparative Theology, the Indonesian theologian Bagus Laksana $(2010,7)$ states that ' $\ldots$ the challenge of comparative theology, itself an offspring of some cultural and religious interstices of our time, is then precisely to seek out further, or to create if necessary, these in-between spaces ...'.

By underlining the necessity of creating joint spaces for theological reflection across religious divides, Laksana's notion of comparative theology comes close to my own understanding of interreligious theology. Like Fletcher (see above), Laksana emphasizes the importance of bodily encounters as a trigger for comparative or interreligious theology: 'This kind of sensory encounter with the other [Laksana refers particularly to faith-transcending pilgrimages] is one of the forms of encounters that enables each religious tradition to re-imagine themselves beyond normal boundaries' (15). ${ }^{7}$ In theological terms, Laksana (much like Buber in his reasoning of the spirit-filled realm of between) suggests that ' $\ldots$ the in-between spaces should also be understood, ultimately as a milieu of divine revelation, a space of our struggle to understand God better' (15). But equally important is his pragmatic recognition that inbetween spaces for doing theology do not fall from heaven but must - 'if necessary' - be created, in touch with lived, sensory experience.

Returning to the Scriptural Reasoning movement and its emphasis on people and scripture, David Ford speaks of 'inbetweenness' as a significant expression of how and where this type of theological endeavour takes place. As one can see from the following quotation, Ford's superabundant application of the term 'space between' oscillates between metaphor and concrete location, between space and place:

It [Scriptural Reasoning] is concerned with what happens in the interpretative space between the three scriptures; in the social space between mosque, church and synagogue; in the intellectual space between 'houses' and 'campuses', and between the disciplines on the campuses; in the religious and secular space between the

\footnotetext{
${ }^{7}$ Laksana qoutes Bhabha: ' $\ldots$ the space of representation, where the image - missing person, invisible eye, Oriental stereotype - is confronted with its difference, its Other' (Laksana 2010, 16, quoting Bhabha 1994, 66).
} 
houses and the various spheres and institutions of society; and in the spiritual space between interpreters of scripture and God. (Ford 2006, 12)

In all these places and spaces between, interreligious theology can be done - as public theology related to joint action for the common good, ritual hospitality, hybrid forms of lived religion, and thoughtful dialogue about matters of faith.

In the ensuing reflections, I shall focus on university theology - done in 'campuses' as a space for doing contextual theology in a comprehensive and multi-faceted sense.

\section{University theology and the secular university}

The term 'university theology' has mostly been used in the German and Scandinavian contexts in reference to theology as done on university 'campuses', that is, in the cross-disciplinary context of the secular university. It approximates to Tracy's vision of a 'public theology' in dialogue with the churches, the academy and the society at large (see above). Correspondingly, Ömer Özsoy $(2015,62)$ of the Institute for the Study of Islamic Culture and Religion in Frankfurt speaks of a self-reflective Islamic theology which - when done in a university context - may become an inspiration for society in its entirety.

Although originating in a Northern European environment, the term university theology has also been used with reference to the Turkish academic context, where many secular universities include a faculty of theology. In the view of Felix Körner $(2005,57)$,

Turkish Ilâhiyat Faculties are explicitly oriented towards enlightened Islam, scientific dialogue and Western-style theology; they are embedded in universities; they therefore operate under the Ministry of Education rather than under a religious authority or private institutions; in that, they are a unique construction in the world of Islam.

The liberal-democratic framework of university theology (which in the case of Turkey was seriously threatened by President Erdoğan's dismissal of a large number of academics after the attempted coup in 2016) may be seen as a formatting factor in a process in which theology is both influenced by and critically discusses dominant values in academia and in the wider society. In Christian as well as Islamic contexts, university theology is strongly associated with academic freedom, although in constructive interaction with the religious tradition in question 
(Özsoy 2015, 62). Özsoy also associates university theology with the possibility of dialogue between world views and faiths in the academic context (56).

This is in tune with the self-understanding of Protestant and Catholic university theologies in the Northern European tradition, where critical dialogue with the surrounding society has been a defining feature. Klaus von Stosch of Paderborn University's Centre for Comparative Theology and Cultural Studies speaks of the entanglement of 'liberal', 'critical' and 'public' impulses in this theological tradition. He also emphasizes the secular element of university theology, seeing secularity as a 'third position' in the spaces between different confessional theologies:

European theology informed by atheism can help remind comparative [or interreligious] theology not to forget the importance of secular questions and ideas ... the instance of a third position could be established by the position of a philosophically autonomous, critical, external perspective ... It is very important that in different countries and different universities the idea of a third position is fulfilled in varying ways, which will effectively stimulate and strengthen this field. (von Stosch 2012, 989)

Similarly, Perry Schmidt-Leukel in his Interreligiöse Theologie. Chancen und Probleme relates his understanding of European theology in secular environments to the very idea of universitas (which is, of course, much older than the modern notion of secularity). He argues that only when confessional theology refers itself to questions of universal truth and relates its work to the totality of reality - that is, to universitas - can it defend its place in the university (SchmidtLeukel 2013, 33). That is, the university has no place for a theology that is merely cultivation of tradition.

The same applies (I would say) to interreligious theology: It only deserves to be called university theology if it relates critically and constructively to faith-transcending issues - ethical, political, philosophical - arising from its secular and religiously pluralistic surroundings. According to Schmidt-Leukel (30), the next important step would be to transcend the mere coexistence of multireligious perspectives, heading for a constructive, multireligious theological effort. Importantly, he also associates interreligious theology with a readiness for 'revision', 
when faced with secular modernity as a common challenge and exposed to the pluralistic tendencies in the different religions (40f.). ${ }^{8}$

Will recent initiatives aimed at making space for Islamic theology in European universities change the way in which Islamic and Christian theology is done - through longterm cooperation between theologians from different traditions? What kind of 're-vision' might it entail, if university theology is done in dialogue with other academic disciplines, with other religious traditions, with lived religion, and with value discourses in larger society?

\section{What is home?}

In conclusion, some reflections on the relevance of comparative or interreligious theology for the 'home' community would be in place. Many proponents of comparative theology emphasize its confessional dimension. Interreligious theology may well also be confessional in the sense of exploring the ethical and theological 'space between' different religious traditions. But in interfaith dialogue, new forms of home (in the sense of deep belonging) may evolve. Reflecting on such experiences, which include the sense of dual or multiple religious belonging, interreligious theology becomes rather a 'transreligious' endeavour, transcending boundaries between religious home communities. According to John J. Thatamanil (2016), such forms of 'transreligious theology' can be seen as 'a quest for interreligious wisdom'.

This mode of doing theology is captured by Tinu Ruparell $(2013,121)$ and his notion of 'interstitial theology', understood as 'a form of cross-cultural philosophy which seeks to consciously hybridize elements of disparate traditions to better articulate the religious location of many people living in pluralistic societies'. Rather than searching for what is meaningful for any particular tradition, interstitial theology applies a 'hybrid hermeneutics' aimed at 'the construction of liminal, hybrid perspectives or standpoints for continuing the conversation of religions in a creative and open-ended way' (121). Also utilizing the metaphor of 'the space in between' (128), Ruparell suggests that in this way of doing theology, '[a] mutually shared area of reference, existing necessarily and only in relation to the conversants, is built up in the interstice which separates them' (129).

Whereas Ruparell's notion of interstitial theology might seem to tune in well with the complex realities of lived religion, Catherine Cornille $(2014,14)$ critically comments that 'it is not evident who would benefit from such insight or theology ... if these ideas become

${ }^{8}$ See also the title of Felix Körner's book Revisionist Koran Hermeneutics in Contemporary Turkish University Theology: Rethinking Islam (2005). In his book, Körner analyses the innovative hermeneutical work on the Qur'an by the so-called Ankara school. 
completely separated from a living faith or from a community of theological reflection, they have little chance of gaining much impact'. Or will multireligious university theologies, applying hybrid hermeneutics and developing in the space between living religious traditions, in fact create new 'homes' where theology can be done - by teachers and students - in critical conversation with other faiths and in deep dialogue with increasingly hybrid forms of lived religion?

Cornille (13) associates Ruparell's reflections on hybrid hermeneutics and interstitial theology with the development of new 'syncretistic positions' (cf. Ruparell 2012, 118-121). But the outcome of doing inter- or transreligious theology need not to be syncretistic theology. Interreligious theology does not dissolve differences. It rather explores ethical and theological questions in a collaborative approach, mobilizing differences in a constructive way, and filling the in-between spaces with new meaning. Transreligious theology destabilizes both the notion of difference and that of spaces between, in the recognition that ethical and theological (dis)agreements often cut right across established religious borders. It may still be meaningfully done in common institutional frameworks, in shared spaces (be it tents or campuses) for common action and reflection. But the complexity of pluralist societies and individual identities requires that interreligious theology must expand its horizon so as to become transreligious theology as well.

\section{References}

Adams, Nicholas. 2011. "Scriptural Reasoning and Interfaith Hermeneutics.” In Interreligious Hermeneutics in Pluralistic Europe: Between Texts and People, edited by David Cheetham, Ulrich Winkler, Oddbjørn Leirvik and Judith Gruber, 59-78. Amsterdam: Rodopi.

Agai, Bekim, et al. 2014. "Islamische Theologie in Deutschland. Herausforderungen im Spanningsfeld divergierender Erwartungen.“ Frankfurter Zeitschrift für IslamischTheologische Studien 1: 7-28.

Askari, Hasan. 1972. "The Dialogical Relationship between Christianity and Islam." Journal of Ecumenical Studies 9: 477-487.

Bhabha, Homi. 1994. The Location of Culture. London: Routledge.

Buber, Martin. 1987. I and Thou. Edinburgh: T\&T Clark.

Buber, Martin. 2002. Between Man and Man. London: Routledge. 
Cheetham, David. 2005. "The University and Interfaith Education.” Studies in Interreligious Dialogue 15 (1): 16-35.

Clooney, Francis. 2010. Comparative Theology: Deep Learning across Religious Borders. Chichester: Wiley-Blackwell.

Clooney, Francis. 2013. "Comparative Theology and Inter-Religious Dialogue.” In The WileyBlackwell Companion to Inter-Religious Dialogue, edited by Catherine Cornille, 51-63. Chichester: Wiley-Blackwell.

Cornille, Catherine. 2014. "The Confessional Nature of Comparative Theology." Studies in Interreligious Dialogue 24 (1): 9-17.

Dunbar, Scott Daniel. 1998. "The Place of Interreligious Dialogue in the Academic Study of Religion.” Journal of Ecumenical Studies 35 (3-4): 455-470.

Fletcher, Jeannine Hill. 2014. "What Counts as 'Catholic'? What Constitutes 'Comparative'?” Studies in Interreligious Dialogue 24 (1): 78-85.

Flood, Gavin. 1999. Beyond Phenomenology: Rethinking the Study of Religion. London: Cassell.

Ford, David. 2006. “An Interfaith Wisdom: Scriptural Reasoning between Jews, Christians and Muslims," In The Promise of Scriptural Reasoning, edited by D. Ford and C. C. Pecknold, 1-22. Oxford: Blackwell.

Ford, D., and C. C. Pecknold, eds. 2006. The Promise of Scriptural Reasoning. Oxford: Blackwell.

Grung, Anne Hege. 2011. “Interreligious Dialogue: Moving between Compartmentalization and Complexity." Approaching Religion 1 (1): 25-32.

Grung, Anne Hege. 2015. Gender Justice in Muslim-Christian Readings: Christian and Muslim Women in Norway Making Meaning of Texts from the Bible, the Koran, and the Hadith. Leiden: Brill Rodopi.

Hedges, Paul. 2013. “Interreligious Studies.” In Encyclopedia of Sciences and Religion, edited by A. Runehov and L. Oiviedo, 1076-1080. New York: Springer.

Hogan, Linda, and John D'Arcy May. 2011. "Visioning Ecumenics as Intercultural, Interreligious, and Public Theology." Concilium 47 (1): 70-81.

Khorchide, Mouhanad. 2015. Gott glaubt an den Menschen. Mit dem Islam zu einem neuen Humanismus. Freiburg: Herder.

Kraemer, Joel L. 1986. Humanism in the Renaissance of Islam: The Cultural Revival during the Buyid Age. Leiden: E.J. Brill. 
Körner,Felix. 2005. Revisionist Koran Hermeneutics in Contemporary Turkish University Theology: Rethinking Islam. Würzburg: Ergon.

Laksana, A. Bagus. 2010. “Comparative Theology: between Identity and Alterity.” In The New Comparative Theology: Interreligious Insights from the Next Generation, edited by Francis Clooney, 1-20. London: T\&T Clark.

Leirvik, Oddbjørn. 2002. Islamsk etikk: Ei idéhistorie. Oslo: Universitetsforlaget.

Leirvik, Oddbjørn. 2014. Interreligious Studies: A Relational Approach to Interfaith Activism and the Study of Religion. London: Bloomsbury.

Leirvik, Oddbjørn. 2016a. “Interreligiøs universitetsteologi.” Teologisk Tidsskrift 5 (2): 156172.

Leirvik, Oddbjørn. 2016b. “Islamic University Theology.” Studia Theologica 70 (2): 127-144. Levinas, Emmanuel. 1998. Of God Who Comes to Mind. Palo Alto, CA: Stanford University Press.

Meir, Ephraim. 2015. Interreligious Theology: Its Value and Mooring in Modern Jewish Philosophy. Berlin: De Gruyter and Magnes.

Miskawayh, Ahmad Ibn Muhamnmad. 1968. The Refinement of Character. Beirut: American University Press of Beirut.

Moyaert, Marianne, and Joris Geldhof, eds. 2015. Ritual Participation and Interreligious Dialogue Boundaries, Transgressions and Innovations. London: Bloomsbury.

Özsoy, Ömer. 2015. "Islamische Theologie als Wissenschaft: Funktionen, Methoden, Argumentationen.” In Zwischen Glaube und Wissenschaft: Theologie in Christentum und Islam, edited by Mohammed Gharaibeh, Esnaf Begic, Hansjörg Schmid and Christian Ströbele, 56-68. Regensburg: Pustet.

Pears, Angie. 2010. Doing Contextual Theology. New York: Routledge.

Ricoeur, Paul. 1995. Oneself as Another. Chicago, IL: University of Chicago Press.

Ruparell, Tinu. 2013. "Inter-Religious Dialogue and Interstitial Theology." In The WileyBlackwell Companion to Inter-Religious Dialogue, edited by Catherine Cornille, 117132. Chichester: Wiley-Blackwell.

Schmidt-Leukel, Perry. 2013. "Interreligiöse Theologie und die Theologie der Zukunft." In Interreligiöse Theologie: Chancen und Probleme, edited by Reinhold Bernhardt and Perry Schmidt-Leukel, 23-42. Zürich: Theologischer Verlag.

Thatamanil, John J. 2016. “Transreligious Theology as the Quest for Interreligious Wisdom: Defining, Defending, and Teaching Transreligious Theology." Open Theology 2 (1): 354-362. 
Tracy, David. 1987. “Comparative Theology.” In Encyclopedia of Religion, vol. 14, 446-455. New York: Macmillan.

Tracy, David. 1991. The Analogical Imagination: Christian Theology and the Culture of Pluralism. New York: Crossroad.

von Stosch, Klaus. 2012. "Comparative Theology as Liberal and Confessional Theology." Religions 3 (4): 983-992.

Vroom, Henk. 2008. “A Theological Faculty as a House with Many Mansions: On the Institutionalization of Theology in Pluralistic, Secular Society." Studies in Interreligious Dialogue (18) 2: 184-202. 